\title{
Preparation of Cattle Feed Blocks Using Agricultural Wastes
}

\author{
${ }^{1} \mathrm{~K}$ M W H Kulathunga, ${ }^{2} \mathrm{~K}$ Y H D Shantha and ${ }^{1} \mathrm{~W}$ A D Nayananjalie \\ ${ }^{1}$ Department of Animal and Food Sciences, Faculty of Agriculture, Rajarata University of Sri Lanka, \\ Puliyankulama, Anuradhapura, Sri Lanka \\ ${ }^{2}$ Department of Agriculture and Post-Harvest Technology, National Engineering Research and Development \\ Center, IDB Industrial Estate, Ekala, Ja-ela, Sri Lanka
}

\begin{abstract}
Scarcity of high quality feeding materials is one of the major constraints in Sri Lankan dairy industry and the study was conducted to prepare a nutritious, conservable and cost effective cattle feed block. Four nutritionally diverse feed blocks (B1, B2, B3 and B4) were prepared incorporating different agricultural wastes. Five treatment diets; T1 (only fresh CO3 grass), T2, T3, T4 and T5 (each with $5 \mathrm{~kg}$ fresh $\mathrm{CO} 3+\mathrm{B1}, \mathrm{B2}, \mathrm{B3}$ and B4 respectively) were tested in on-farm trial using fifteen Jursey $x$ Sahiwal cross bred heifers. Daily feed intake and live weight gain of each animal were measured. Data were analyzed using one way Analysis of Variance in SAS. Among the feed blocks, B3 was prepared with 65\% paddy straw, $10 \%$ rice bran, $10 \%$ coconut poonac, $10 \%$ molasses, $2 \%$ urea, $2 \%$ salt, $0.5 \% \mathrm{DCP}$ and $0.5 \%$ lime and contained $89.6 \%$ dry matter, $14.5 \%$ crude protein, $1.5 \%$ crude fat, $30.7 \%$ fiber, $0.9 \%$ Calcium and $0.7 \%$ Phosphorus. Average daily dry matter intake and live weight gain of heifers fed with T2, T3 and T5 diets were higher ( $p<0.05)$ compared to the heifers fed with T1 and T4. The highest $(p<0.05)$ average daily feed intake and live weight gain were recorded in heifers fed with T3 diet. All feed blocks could be kept for 45 days under sealed polyethylene package without any quality deterioration. Thus, block 3 could be recommended as the best feed block that to be fed with fresh forages having protein and energy balance at low cost.
\end{abstract}

KEYWORDS: Agricultural wastes, dairy, feed block 


\section{INTRODUCTION}

Dairy cattle make a major contribution to both national and household economies providing milk, which contains essential nutrients (Abeygunawardena, Rathnayake \& Jayathilake, 1997). However, dairy industry in Sri Lanka is not selfsufficient and local dairy production is nearly $33 \%$ of the requirement of current consumption rate. The balance amount is supplied by the import parity which cost around 27 billion rupees annually (Central Bank Report, 2012).

The basic requirements of dairy cow for maximum production include good feed and clean water, good health, comfortable environment and to exploit the cow's full genetic potential, there is a need to have a good nutrition program to meet all the needs (Perera, Siriwardene \& Premaratne, 1999). Hence nutrition plays a vital role on the performance, health, and welfare of dairy cattle. One of the major constraints faced by the dairy farmers in the dry zone and up country commercial farms is the severe drop in body condition during prolonged droughts due to scarcity of feed (Ibrahim \& Jayatileka, 2000). Therefore, forage diets need to be supplemented with an additional energy or protein source (concentrates) and minerals to satisfy the cows' nutritional requirements. In order to ensure a steady supply of quality feeds for livestock even during the dry season, excess forages could be preserved as silage, hay and feed blocks (Ranawana, 2008).

From the technical and scientific points of view, the block technology works reliably in improving livestock productivity. Cattle feed block which made with handy manner is included all the nutritious compounds at required level of animal. These blocks can be improved nutritionally by mixing dry forages or legumes with other feed ingredients such as coconut poonac, rice bran and shell grids etc. They can also be used as an effective feed for livestock, especially for dairy cows during the drought period (Somasiri et al., 2010). Use of feed blocks rather than forage feeding may positively affect to the both animal and the farmer. In animal's side, it fulfills daily nutritional requirement of animal with less possibilities in digestive disorders like bloat, acidosis, etc. Further, blocks are palatable than feeding sole forage or hay. In the farmer's point of view, feed blocks can be easily handled, stored and transported. Moreover, these can be used for feeding cows during forage scarcity periods and animals can be reared with minimal space under intensive conditions (Machen, 2005).

Therefore, this study was carried out to prepare a nutritious, conservable and cost effective cattle feed block using agricultural waste materials as an alternative feed source during forage scarcity.

\section{METHODOLOGY}

\section{Feed Block Preparation}

Four feed blocks were formulated for dairy heifers according to the NRC (2007) recommendations by incorporating different agro wastes with different binders (Table 1) and compressed into a block as follows.

All raw ingredients were visually inspected and ingredients with any deteriorating sign were rejected. Straw was chopped into small pieces and coconut poonac and rice bran were prepared into a powder. Molasses was boiled at $70^{\circ} \mathrm{C}$ to facilitate uniform application. Raw ingredients were weighted separately according to the formula. Feed mixing machine was cleaned well and straw, coconut poonac, rice bran and cement or wheat flour was mixed thoroughly (Plate 1). Other micro ingredients like urea, salt, di-calcium phosphate (DCP) and lime were dissolved in molasses or water and applied into straw concentrates mixture using a spray gun. 
Treatment blocks were mixed as bulk and divided into $5 \mathrm{~kg}$ portions.

Well mixed $5 \mathrm{~kg}$ raw feed ingredients were loaded to the hydraulic block forming machine (Plate 2) manually. Compressed blocks were formed by applying 120 psi hydraulic pressure for 4 minutes. Feed blocks were packed in polyethylene covers and sealed immediately and stored under proper storage.

Table 1. Raw ingredients composition in prepared feed blocks

\begin{tabular}{|l|c|c|c|c|}
\hline $\begin{array}{l}\text { Raw } \\
\text { ingredients } \\
(\%)\end{array}$ & $\begin{array}{l}\text { Block } \\
\mathbf{0 1}\end{array}$ & $\begin{array}{l}\text { Block } \\
\mathbf{0 2}\end{array}$ & $\begin{array}{l}\text { Block } \\
\mathbf{0 3}\end{array}$ & $\begin{array}{l}\text { Block } \\
\mathbf{0 4}\end{array}$ \\
\hline Straw & 65 & 65 & 65 & 65 \\
\hline Rice bran & 20 & 10 & 10 & 20 \\
\hline $\begin{array}{l}\text { Coconut } \\
\text { poonac }\end{array}$ & - & 10 & 10 & - \\
\hline Molasses & 10 & - & 10 & - \\
\hline Cement & - & 5 & - & - \\
\hline Wheat flour & - & - & - & 5 \\
\hline Water & - & 5 & - & 5 \\
\hline Urea & 2 & 2 & 2 & 2 \\
\hline Salt & 2 & 2 & 2 & 2 \\
\hline DCP & 0.5 & 0.5 & 0.5 & 0.5 \\
\hline Lime & 0.5 & 0.5 & 0.5 & 0.5 \\
\hline
\end{tabular}

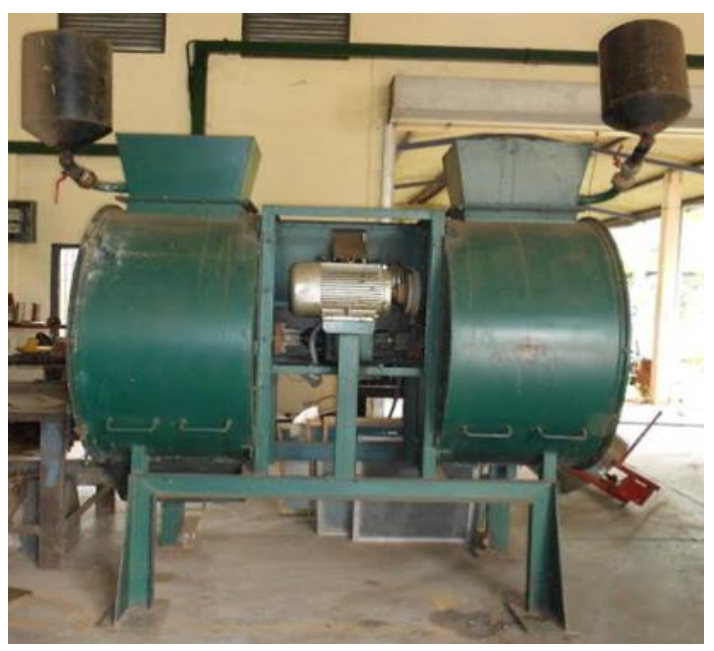

Plate 1. Feed mixturer

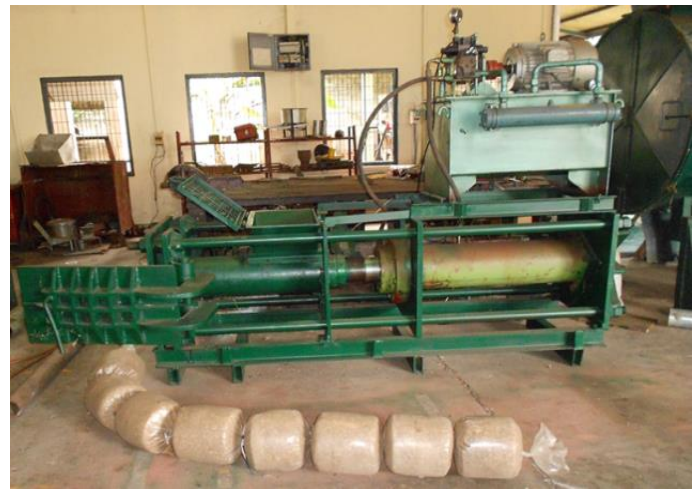

Plate 2. Block forming machine

\section{Animal experimental}

Fifteen Jursey $\times$ Sahiwal cross bred heifers (about 6 - 10 month age with 3 average body weight groups; $90-120 \mathrm{~kg}, 120$ - $150 \mathrm{~kg}, 150$ - $180 \mathrm{~kg}$ ) were selected. Three heifers from each weight group were randomly assigned into five treatments. Experiment was conducted as a Complete Randomized Design (CRD). Animals were separated by providing individual feeding cages and fed with 4\% from animals' body weight plus 5\% excess (DM basis) per a day. Feed blocks were broken into pieces and mixed with fresh forages before feeding. During 7 days of adaptation period, blocks were provided as five treatment $(\mathrm{T} 1=$ Only fresh CO3 grass, T2 = Block $01(\mathrm{~B} 1)+5 \mathrm{~kg}$ fresh $\mathrm{CO} 3, \mathrm{~T} 3=$ Block $02(\mathrm{~B} 2)+5 \mathrm{~kg}$ fresh $\mathrm{CO} 3, \mathrm{~T} 4=$ Block $03(\mathrm{~B} 3)+5 \mathrm{~kg}$ fresh $\mathrm{CO} 3$ and $\mathrm{T} 5=$ Block $04(\mathrm{~B} 4)+5 \mathrm{~kg}$ fresh $\mathrm{CO} 3$ ) and data were collected for a period of 14 days.

\section{Sample analysis and data collection}

Feed samples (100 g) were collected from each $50 \mathrm{~kg}$ bulk mixtures separately. Collected feed samples were dried and ground to pass through a $1 \mathrm{~mm}$ mesh and stored in sample bottles until further analysis. All feed samples (from B1, B2, B3 and B4) 
were analyzed for dry matter, crude protein, crude fiber, fat, calcium and phosphorus according to the Association of Official Analytical Chemist (AOAC) (1998).

The initial weight of provided feeds and weight of remaining feeds after 24 hours were measured and daily dry matter intake was calculated for individual animals. According to the intake, feed cost per animal per day was noted. Live weights of animals were taken at the beginning of the trial and daily. Body weight was measured using the standard weigh band (Farmer's Boy - Patent No. 812717). Live weight gain per day and feed conversion ratio (FCR) were calculated. Daily dry matter intake, daily live weight gain, FCR, feeding cost and nutritional status were analyzed using One Way Analysis of Variance (ANOVA) procedure in Statistical Analyzing Software (SAS ver. 9.0). Individual heifer was used as the experimental unit. Mean separation was done by Tukey's Studentized Range Test (TSRT) and statistical significance was declared at $p$ $<0.05$.

\section{RESULTS AND DISCUSSION}

Proximate composition of cattle feed blocks (B1, B2, B3, B4) prepared using different agricultural wastes were shown in Table 2. Feed block 03 (B3) contained high amount of crude protein (14\%) and gross energy $(3000 \mathrm{kcal} / \mathrm{kg}$ ) compared to other feed blocks. Crude fiber contents were not much different among feed blocks (28 - 30\%). Higher $\mathrm{Ca}$ and $\mathrm{P}$ contents were recorded in block 02 (B2), may be due to addition of cement as a binding agent. Because cement contains more than $25 \%$ of lime or calcium oxide by weight (Mindess \& Young, 1981). Daily digestible energy and crude protein requirement of one year old dairy heifer is $2.89 \mathrm{Mcal}$ and $12 \%$ respectively (NRC, 2001). Therefore, the feeding of $7-8 \mathrm{~kg}$ block diets (per day) can fulfill the daily nutritional requirement of one year old dairy heifer.

Table 2. Proximate composition of feed blocks

\begin{tabular}{|l|c|c|c|c|}
\hline Composition & $\begin{array}{c}\text { Block } \\
\mathbf{0 1}\end{array}$ & $\begin{array}{c}\text { Block } \\
\mathbf{0 2}\end{array}$ & $\begin{array}{c}\text { Block } \\
\mathbf{0 3}\end{array}$ & $\begin{array}{c}\text { Block } \\
\mathbf{0 4}\end{array}$ \\
\hline $\begin{array}{l}\text { Dry matter } \\
(\%)\end{array}$ & 91.3 & 90.0 & 89.6 & 86.6 \\
\hline $\begin{array}{l}\text { Gross energy } \\
\text { (kcal/kg) }\end{array}$ & 2800 & 2800 & 3000 & 2700 \\
\hline $\begin{array}{l}\text { Crude } \\
\text { protein (\%) }\end{array}$ & 10.0 & 12.5 & 14.5 & 09.0 \\
\hline $\begin{array}{l}\text { Ether extract } \\
(\%)\end{array}$ & 0.35 & 1.10 & 1.50 & 0.30 \\
\hline $\begin{array}{l}\text { Crude fiber } \\
(\%)\end{array}$ & 28.72 & 28.12 & 30.70 & 28.20 \\
\hline Ca (\%) & 0.84 & 1.45 & 0.95 & 0.74 \\
\hline P (\%) & 0.63 & 1.00 & 0.72 & 0.50 \\
\hline
\end{tabular}

There was a significant difference $(p$ $<0.05)$ in daily dry matter intake of heifers fed with different treatment diets during study period (Table 3). Daily dry matter intake of heifers fed with T3 (Block $3+$ fresh CO3) was significantly higher $(p<0.05)$ than heifers fed with $\mathrm{T} 1$ (only fresh $\mathrm{CO} 3$ ) and $\mathrm{T} 4$ (Block $2+$ fresh CO3). The lowest and highest dry matter intakes were observed in heifers fed with $\mathrm{T} 4$ (Block $02+$ fresh CO3) and $\mathrm{T} 3$ (Block $03+$ fresh $\mathrm{CO} 3$ ) respectively. There was no significant difference $(p>0.05)$ in daily dry matter intake of heifers fed with T2 (Block $1+$ fresh CO3), T3 (Block $3+$ fresh $\mathrm{CO} 3)$ and $\mathrm{T} 5$ (Block $4+$ fresh $\mathrm{CO} 3)$. Heifers fed with T2 and T3 diets recorded comparatively higher daily intakes and $\mathrm{T} 2$ and T3 diets may be more palatable due to addition of molasses as a binder.

Numerous researchers have reported that inclusion of molasses increased the intake of fibrous basal diet (Kimambo, Makiri \& Shem, 1992; Premaratne, 1993). This is due to sweet in taste and increased availability of fermentable nitrogen and other nutrients required by the rumen bacteria (Nguyen, 2003). 
Table 3. Daily dry matter (DM) intake and weight gain of heifers fed with different treatment diets

\begin{tabular}{|c|c|c|}
\hline Treatments & $\begin{array}{c}\text { DM intake } \\
\text { (kg / day) }\end{array}$ & $\begin{array}{c}\text { Weight gain } \\
\text { (kg / day) }\end{array}$ \\
\hline $\mathrm{T} 1$ & $4.5 \pm 0.2^{\mathrm{b}}$ & $0.28 \pm 0.07^{\mathrm{b}}$ \\
\hline $\mathrm{T} 2$ & $5.0 \pm 0.4^{\mathrm{ab}}$ & $0.40 \pm 0.04^{\mathrm{ab}}$ \\
\hline $\mathrm{T} 3$ & $5.6 \pm 0.5^{\mathrm{a}}$ & $0.50 \pm 0.04^{\mathrm{a}}$ \\
\hline $\mathrm{T} 4$ & $4.3 \pm 0.4^{\mathrm{b}}$ & $0.33 \pm 0.04^{\mathrm{b}}$ \\
\hline $\mathrm{T} 5$ & $4.8 \pm 0.3^{\mathrm{ab}}$ & $0.37 \pm 0.07^{\mathrm{ab}}$ \\
\hline
\end{tabular}

${ }^{a, b}$ Means within the same column with different superscripts are significantly different $(p<0.05)$.

Daily weight gain of heifers fed with different treatment diets was significantly different ( $p<0.05$, Table 3). Daily weight gain of heifers fed with T3 was significantly higher $(p<0.05)$ than T1 and T4 fed heifers. There was no significant difference $(p>0.05)$ in daily weight gain of heifers fed T2, T3 and T5. At the end of the study period, the highest and lowest daily weight gains were recorded in heifers fed with $\mathrm{T} 3$ and $\mathrm{T} 1$ diets respectively. The lowest weight gain was recorded in $\mathrm{T} 1$ diet may be due to reduced body conditions of heifers which affected with diarrhea during study.

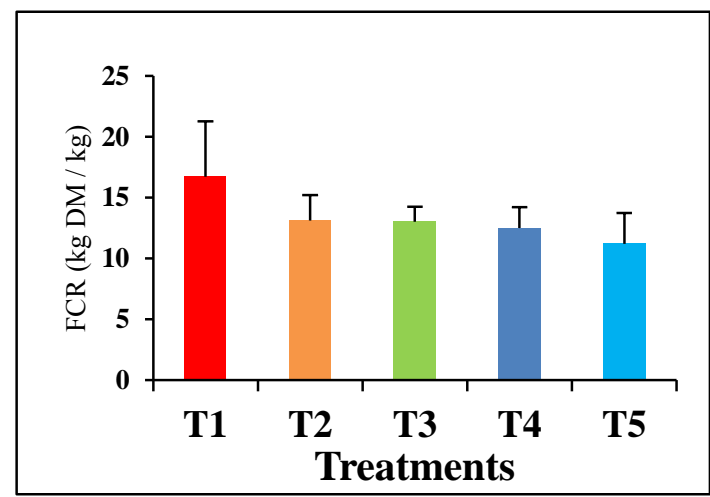

Figure 1. Feed conversion ratio of heifers fed with different treatment diets

There were no differences $(p>0.05)$ in FCR among heifers fed with five treatment diets during the study period (Figure 1). Numerically, heifers fed with T5 were shown the lowest FCR and heifers fed with T1 were shown the highest FCR.

Table 4. Daily feeding costs of treatment diets

\begin{tabular}{|c|c|}
\hline Treatment & Feed cost ( Rs:/ day) \\
\hline T1 & $189.07 \pm 8.63^{\mathrm{a}}$ \\
\hline T2 & $137.17 \pm 7.42^{\mathrm{c}}$ \\
\hline T3 & $160.67 \pm 4.04^{\mathrm{b}}$ \\
\hline T4 & $107.60 \pm 6.60^{\mathrm{d}}$ \\
\hline T5 & $136.07 \pm 6.22^{\mathrm{c}}$ \\
\hline
\end{tabular}

Data are presented as mean $\pm \mathrm{SD}$ a,b,c,d Means within the same column with different superscripts are significantly different $(p<0.05)$

The highest $(p<0.05)$ daily feeding cost of heifers was recorded when animals fed only with fresh CO3 grass (Table 4), because average cost for production of $1 \mathrm{~kg}$ dry matter from fresh $\mathrm{CO} 3$ was relatively higher than production of $1 \mathrm{~kg}$ dry matter from feed block containing diets. Generally fresh $\mathrm{CO} 3$ grass contains $80-82 \%$ moisture by weight (Bogdan, 1977). Further, there was no significant difference $(p>0.05)$ in daily feeding cost when heifers fed with T2 and T5. The least $(p<0.05)$ feeding cost was recorded when heifers fed with $\mathrm{T} 4$. It could be due to use of cement as a binder with low cost and in other blocks, molasses or wheat flour was used as a binder with a higher cost.

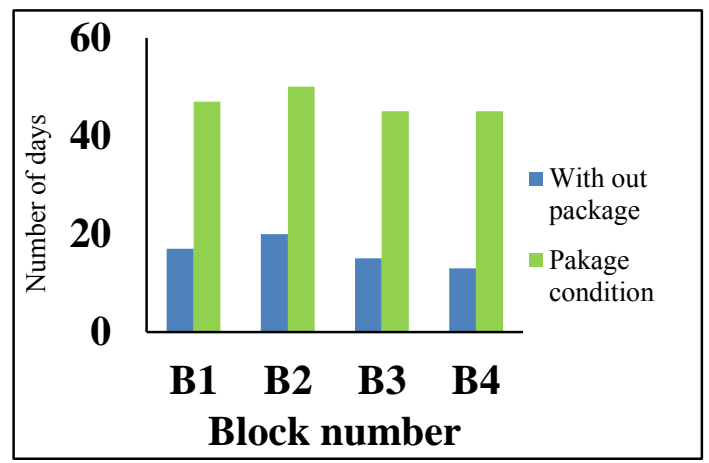

Figure 2. Shelf life of feed blocks 
Shelf life of the prepared feed blocks was higher under polyethylene packaging compared to non package (Figure 2). Feed blocks could be kept maximum 45 days without any quality deterioration under package and proper storage conditions. Feed blocks without a package could be kept maximum 15 days under atmospheric conditions.

\section{CONCLUSIONS}

Feed block technology is one of the effective alternative feeding methods for dairy cattle during forage scarcity periods. Block 03 (B3) can be recommended as the best to be fed with little amount of fresh forages having protein and energy balance during roughage scarcity at low cost.

\section{REFERENCES}

ABEYGUNAWARDENA

$\mathrm{H}$, RATHNAYAKE D \& JAYATHILAKE WMAP. Characteristics of Cattle Farming Systems in Sri Lanka. Journal of Natural Science Council of Sri Lanka. . 1997; 25(1): $25-38$.

ASSOCIATION OF
ANALYTICAL CHEMIST (AOAC) $(1995)$.
Official Methods of Analysis $\left(16^{\text {th }}\right.$ Ed),
Association of Analytical Chemists,
Washington, DC.

BOGDAN AV. Tropical Pasture and Fodder Plants. Longman Group Limited, London. 1977; $233-244$.

CENTRAL BANK REPORT. Annual report, Central bank of Sri Lanka. 2012.

IBRAHIM MN \& JAYATILEKA TN. Livestock Production under Coconut Plantations in Sri Lanka: Cattle and Buffalo Production Systems. Asian Australasian J. of Animal Sci. 2000; 13(1) : 60-67.
KIMAMBO AE, MAKIRI AM \& SHEM MN. The use of Leucaena leucocephala supplementation to improve the utilization of maize stover by sheep. In STARES, J.E.S. \& SAID, A.N. (Eds). Complementary of feed resources for animal production in Africa. Proceedings of Joint Feed Resources Networks Workshop, Botswana. 1992; 430.

MACHEN R. Block and Cub Supplementation for Grazing Beef Cattle. Texas Cooperative Extension Journal. 2005; Retrieved on May 20, 2014, from http:///sutton.agrilife.org. .

MINDESS S \& YOUNG JF. Concrete, Prentice-Hall, Inc., Englewood Cliffs, NJ. $1981 ; 671$.

NGUYEN VH. Utilization of Gliricidia leaves (Gliricidia maculata) as a protein source for dairy goats. In PRESTON, R. \& OGLE, B. (Eds). Proceeding of Final National Seminar Workshop on Sustainable Livestock Production on Local Feed Resources. HUAF-SAREC, Hue City. 2003.

NATIONAL RESEARCH COUNCIL (NRC). Nutrient Requirements of Dairy Cattle National Academy of Sciences, Washington, USA. 2001.

PERERA ANF, SIRIWARDENE JA, DE S \& PREMARATNE S. Fibrous Crop Residues as a Ruminant Feed. Cattle and Buffalo Farming, Handbook for Veterinarians. 1999.

RANAWANA S. Dairy Industry in Sri Lanka: Problems and Prospects. Economic Review, Dairy Industry Problems and Prospects, Research Department of People's Bank Head Office, Colombo, Sri Lanka. 2008.

SOMASIRI SC, PREMARATNE SH, ABEYSOMA A, DEMATAWEWA CMB \& SATSARA JHMN. Effect of Gliricidia 
(Gliricidia sepium) Leaf Meal Blocks on Intake, Live Weight Gain and Milk Yield of Dairy Cows. Journal of Tropical Agricultural Research. 2010; 22 (1): $76-83$. 